\title{
NILAI BUDAYA DALAM CERITA RAKYAT HIKAYAT DATUK TUAN BUDIAN DAN SULTAN DOMAS PEMIMPIN YANG SAKTI DAN BAIK HATI
}

\section{CULTURAL VALUE IN FOLKLORE HIKAYAT DATUK TUAN BUDIAN AND SULTAN DOMAS PEMIMPIN YANG SAKTI DAN BAIK HATI}

\author{
Erwin Wibowo \\ Kantor Bahasa Lampung \\ erwin.wibowo@kemdikbud.go.id
}

\begin{abstract}
ABSTRAK
Penelitian ini bertujuan untuk mendeskripsikan nilai-nilai budaya yang terdapat dalam cerita rakyat Hikayat Datuk Tuan Budian, dan Sultan Domas Pemimpin yang Sakti dan Baik Hati. Metode yang digunakan dalam penelitian ini adalah deskriptif dengan data yang berbentuk kata-kata yaitu kutipan-kutipan. Sumber cerita rakyat adalah buku yang berjudul Hikayat Datuk Tuan Budian, dan Sultan Domas Pemimpin yang Sakti dan Baik Hati terbitan Kantor Bahasa Lampung Tahun 2017. Hasil dari penelitian ini adalah terdapat nilai-nilai budaya di dalam dua buku cerita rakyat tersebut. Nilai-nilai budaya yang di dapat antara lain keyakinan, berdoa kepada Tuhan, rajin berdoa, bersyukur kepada Tuhan dan percaya akan rejeki semua berasal dari Tuhan bergotong-royong, hormat menghormati, bertanggung jawab, sifat mementingkan kepentingan umum, penolong, kasih sayang, saling membantu terhadap sesama, hidup rukun, keteladanan, berjiwa penolong, dermawan, cinta damai, sabar, syukur, mandiri, pekerja keras, keteladanan, bijaksana, cinta terhadap lingkungan, keberanian, kewaspadaan, menyakini ajaran agama, dan memanfaatkan alam dengan sebaikbaiknya
\end{abstract}

Kata kunci: nilai budaya, cerita rakyat, Lampung.

\begin{abstract}
This study aims to describe the cultural values contained in the folklore of Hikayat Datuk Tuan Budian, and Sultan Domas Pemimpin yang Sakti dan Baik hati. The method used in this research is descriptive and data in forms of words which are quotations. The source of folklore is a book entitled Hikayat Datuk Tuan Budian, and Sultan Domas Pemimpin yang Sakti dan Baik hati published by Kantor Bahasa Lampung in 2017. Results of this study is there are cultural values in the two books of folklore. Cultural values which can include faith, pray to God, diligent prayer, thanking God and believe in fortune all came from God cooperate, respect, responsible, altruism general, helper and affection, helping each other, living in harmony, exemplary, helpless, generous, and in love of peace, patience, gratitude, independence, hard worker, exemplary, wise, love of the environment, courage, vigilance, belief in religious teachings, and utilizing nature as well as possible
\end{abstract}

Keywords: cultural values, folklore, Lampung. 


\section{PENDAHULUAN}

Sastra dalam perkembangannya selalu memiliki pesan yang tertuang didalamnya. Sastra juga merupakan satu diantara wujud kebudayaan suatu masyarakat yang dituangkan dalam bentuk cerita. Sastra sebagai bentuk kebudayaan adalah seni yang menggambarkan kehidupan manusia.

Cerita rakyat merupakan karya sastra yang didalamnya memuat nilai-nilai kebudayaan suatu daerah. Cerita rakyat dibangun dan dikembangkan melalui bahasa lisan sebagai sarana pengungkapnya. Cerita rakyat adalah cerita yang berkembang pada masyarakat tertentu yang perkembangannya bersifat lisan dari mulut kemulut dan dianggap sebagai milik bersama. Hal ini sejalan dengan pendapat yang dikemukakan oleh Djamaris (1993:15) bahwa cerita rakyat adalah suatu golongan cerita yang hidup dan berkembang secara turun temurun dari suatu generasi kegenerasi berikutnya.

Menurut Danandjaya (1997:2) Cerita rakyat merupakan bentuk sastra rakyat yang berisi cerita-cerita ungkapan, peribahasa nyanyian, tarian, adat resmi, undang-undang, teka-teki permainan (games), kepercayaan dan perayaan (beliefs and festival) semuanya termasuk dalam sastra rakyat. Folklor yang sering diteliti yaitu cerita prosa rakyat. Menurut Bascom dibuku Danandjaja (1997: 50), cerita prosa rakyat dibagi menjadi 3 golongan, yaitu mite (myth), legenda (legend), dongeng (folktale).

Ciri-ciri pengenal utama folklor menurut Danandjaja (1997:3 - 4) adalah: (1) Penyebaran dan pewarisannya biasanya dilakukan secara lisan, yakni disebarkan melalui tutur kata dari mulut ke mulut dari satu (atau dengan suatu contoh yang disertai dengan gerak isyarat, dan alat pembantu pengingat) dari satu generasi ke generasi berikutnya, (2) Folklor bersifat tradisional, yaitu disebarkan dalam bentuk yang relatif tetap atau dalam bentuk standar. Disebarkan di antara kolektif tertentu dalam waktu yang cukup lama (paling sedikit dua generasi), (3) Folklor ada (exist) dalam versi yang berbeda-beda. Hal ini diakibatkan oleh cara penyebarannya yang secara lisan dari mulut ke mulut, dan biasanya bukan melalui catatan atau rekaman, sehingga folklor dengan mudah dapat mengalami perubahan, walaupun demikian perbedaannya terletak pada bagian luarnya saja, sedangkan bentuk dasarnya tetap bertahan, (4) Folklor biasanya bersifat anonim, yaitu nama penciptanya sudah tidak diketahui orang lagi, (5) Folklor biasanya mempunyai bentuk berumus atau berpola, (6) Folklor mempunyai kegunaan (function) dalam kehidupan bersama suatu kolektif, (7) Folklor bersifat pralogis, yaitu mempunyai logika sendiri yang tidak sesuai dengan logika umum. Ciri pengenal ini terutama berlaku bagi folklor lisan dan sebagian lisan, (8) Folklor menjadi milik bersama (collective) dari kolektif tertentu. Hal ini sudah tentu diakibatkan karena penciptanya yang pertama sudah tidak diketahui lagi, sehingga setiap anggota kolektif yang bersangkutan merasa memilikinya, (9) Folklor pada umumnya bersifat polos dan lugu, sehingga seringkali kelihatannya kasar, terlalu spontan. Hal ini dapat dimengerti apabila mengingat bahwa banyak folklor merupakan proyeksi emosi manusia yang paling jujur manifestasinya.

Fungsi cerita rakyat menurut Bascom (Sikki, dkk. 1985:13) mengemukakan fungsi cerita rakyat di antaranya satu, cerita rakyat mencerminkan angan-angan suatu kelompok (kolektif), peristiwa yang diungkap oleh cerita rakyat tidak benar- 
Tuah Talino

Tahun XIII Volume 13 Nomor 2 Edisi 6 Desember 2019

ISSN 0216-079X E-ISSN 2685-3043

Balai Bahasa Kalimantan Barat

benar terjadi dalam kenyataan sehari-hari, tetapi merupakan proyeksi dari anganangan atau impian rakyat jelata. Dua, cerita rakyat digunakan untuk mengesahkan dan menguatkan suatu adat kebiasaan pranata-pranata yang merupakan lembaga kebudayaan masyarakat yang bersangkutan. Tiga, cerita rakyat dapat berfungsi sebagai lembaga pendidikan budi pekerti kepada anak-anak atau tuntutan dalam hidup. Empat, cerita rakyat berfungsi sebagai pengendalian sosial atau alat pengawasan agar norma-norma masyarakat dapat dipenuhi. Sementara menurut Rukmini. 2009:55) cerita rakyat tidak hanya berfungsi sebagai hiburan tetapi juga sarana untuk mengetahui asal-usul nenek moyang, teladan para pendahulu, mengetahui hubungan kekerabatan, mengetahui asal-usul tempat, adat istiadat, dan mengetahui sejarah dari benda pusaka.

Cerita rakyat banyak mengandung nilai-nilai religi dan kemanusiaan didalamnya, yaitu menggambarkan kehidupan budaya manusia pada zamannya. Nilai-nilai yang terkandung dalam karya sastra banyak memberikan teladan bagi masyarakat. Salah satu nilai yang terkandung dalam sastra adalah nilai-nilai tentang budaya. Nilai budaya yang tertuang dalam karya sastra lazimnya menceritakan tentang adat-istiadat dan kebiasaan suatu kelompok masyarakat. Nilai budaya dalam karya sastra sudah sejak lama menghiasi karya sastra dan dapat dijadikan teladan bagi masyarakat itu sendiri.

Nilai budaya terdiri dari konsepsi-konsepsi yang hidup dalam alam pikiran sebagian besar warga masyarakat mengenai hal-hal yang mereka anggap mulia. Dalam kehidupan masyarakat, sistem nilai ini berkaitan dengan sikap dan tingkah laku manusia. Sistem nilai adalah bagian terpadu dalam etika moral yang dijabarkan dalam norma-norma sosial, sistem hukum dan adat yang berfungsi sebagai tata kelakuan untuk mengatur waktu (Koentjaraningrat, 1987:85).

Koentjaraningrat (1990:192 - 193) berpendapat ada tiga pandangan budaya terhadap alam, yaitu pertama, kebudayaan yang memandang alam sebagai sesuatu yang dahsyat sehingga manusia hanya dapat pasrah pada apa yang alam berikan tanpa banyak berusaha. Kedua, kebudayaan yang menganggap bahwa alam merupakan sesuatu yang dapat dilawan manusia sehingga manusia diharuskan untuk menaklukkan alam. Ketiga, kebudayaan yang menganggap bahwa manusia dapat menciptakan keselarasan dengan alam atau dengan kata lain, alam dan manusia membangun hubungan mutualisme (saling menguntungkan).

Djamaris (1996:3) mengungkapkan bahwa nilai budaya dikelompokkan ke dalam lima pola hubungan, yaitu (1) nilai budaya dalam hubungan manusia dengan Tuhan, (2) nilai budaya dalam hubungan manusia dengan alam, (3) nilai budaya dalam hubungan manusia dengan masyarakat, (4) nilai budaya dalam hubungan manusia dengan orang lain atau sesamanya, (5) nilai budaya dalam hubungan manusia dengan dirinya sendiri. Sementara menurut Sarynono (dalam Rukesi,dkk. 2017a:27) nilai budaya memiliki lima jenis kedudukan dan fungsi nilai budaya yaitu sebagai penggerak, pengendali, proyeksi, dan utopia, tolak ukur, serta sebagai tujukan ucapan, tindakan, perbuatan, dan perilaku manusia.

Beberapa penelitian tentang cerita rakyat Lampung pernah dilakukan, antara lain Nilai-Nilai Pendidikan Cerita Rakyat dalam Buku Cerita Rakyat Lampung Karya A. Effendi Sanusi dan Implikasinya dalam Pembelajaran Bahasa Lampung di Sekolah Menengah Pertama yang dilakukan oleh Nur Aminah (2016). Hasil 
dari penelitian ini menunjukkan bahwa terdapat nilai-nilai pendidikan pada cerita rakyat dalam buku Sastra Lisan Lampung karya A.Effendi Sanusi. Nilai-nilai pendidikan itu meliputi nilai pendidikan moral, relegius, sosial, dan nilai budaya. Nilai-nilai pendidikan tersebut dapat diimplikasikan dalam pembelajaran bahasa Lampung di SMP kelas VII semester ganjil pada KD 7.4.5 menanggapi dan menyajikan isi serta nilai nilai yang terkandung di dalam teks waghahan sesuai dengan kaidah-kaidahnya secara lisan dan tulisan. Selain Nur Aminah, penelitian tentang cerita rakyat Lampung juga dilakukan oleh Ahmad Jum'a Khatib Nur Ali (2016) dengan judul Representasi islam dalam Cerita Rakyat Lampung. Cerita rakyat yang dipakai dalam penelitian ini adalah Khadin Tegal dan Sang Kabelah. Penelitian ini menemukan bahwa dua cerita rakyat Lampung tersebut merepresentasikan Islam dengan menggunakan simbolisasi identitas; melalui penamaan, tokoh dan hal-hal simbolik yang merepresentasikan rukun Islam dan iman dalam ajaran agama Islam.

Seperti halnya cerita rakyat yang berkembang di Indonesia. Lampung juga memiliki banyak cerita rakyat yang sudah atau belum di publikasikan. Seperti halnya cerita rakyat yang berkembang di Indonesia, cerita rakyat Lampung juga memiliki nil ai-nilai budaya yang dapat dijadikan panutan oleh masyarakatnya. Oleh karena itu, Tujuan dalam tulisan ini akan mendeskripsikan nilai-nilai budaya dari buku cerita rakyat Lampung yang berjudul Hikayat Datuk Tuan Budian yang ditulis oleh Susilowati dan Sultan Domas Pemimpin yang Sakti dan Baik Hati yang ditulis oleh Yuli Nugrahani.

\section{METODE PENELITIAN}

Metode dalam penelitian ini menggunakan metode kualitatif. Metode penelitian kualitatif merupakan prosedur penelitian yang menghasilkan data deskriptif berupa kata-kata tertulis atau lisan tentang sifat suatu individu, keadaan, atau gejala dari kelompok tertentu yang diamati (Moelong, 2002:6).

Sumber data dalam penelitian ini adalah adalah buku cerita rakyat Lampung yang berjudul berjudul Hikayat Datuk Tuan Budian yang ditulis oleh Susilowati dan Sultan Domas Pemimpin yang Sakti dan Baik Hati yang ditulis oleh Yuli Nugrahani, yang diterbitkan oleh Kantor Bahasa Lampung tahun 2017.

Tujuan utama dari metode ini adalah membuat gambaran tentang suatu keadaan secara objektif dalam situasi yang dihadapi dengan menempuh langkahlangkah pengumpulan data, klasifikasi, dan analisis atau pengolahan data. Bentuk penelitian yang digunakan adalah kualitatif. Alasan penulis menggunakan bentuk penelitian kualitatif karena bentuk penelitian ini bersifat deskriptif dan data yang dianalisis tidak untuk menerima atau menolak hipotesis, melainkan hasil analisis itu berupa deskripsi dari gejala-gejala yang diamati.

\section{PEMBAHASAN}

Pada bagian ini akan mendeskripsikan nilai-nilai budaya yang terdapat di kedua buku cerita rakyat Lampung yang berjudul berjudul Hikayat Datuk Tuan Budian yang ditulis oleh Susilowati dan Sultan Domas: Pemimpin yang Sakti dan Baik Hati yang ditulis oleh Yuli Nugrahani. 


\section{Nilai Budaya dalam Hubungan Manusia dengan Tuhan}

Nilai budaya dalam hubungan manusia dengan Tuhan tercermin pada prilaku antara lain mensyukuri nikmat, berserah diri kepada Tuhan, berdoa kepada Tuhan, dan hanya meminta pertolongan kepada Tuhan. Hal ini merupakan salah satu dasar manusia yaitu homo religious. Djamaris (dalam Ayuningtyas, 2015:8) menyatakan bahwa manusia pada dasarnya adalah homo religious, yaitu makhluk beragama. Homo religious adalah tipe manusia yang hidup dalam satu alam yang sakral, penuh dengan nilai-nilai religius dan dapat menikmati sakralitas yang ada dan tampak dalam semesta alam materi, alam tumbuh-tumbuhan, alam bintang, dan alam manusia. Data yang mewakili nilai budaya dalam hubungan manusia dengan Tuhan yang terdapat dalam cerita rakyat Hikayat Datuk Tuan Budian adalah sebagai berikut.

"Akan tetapi, kami juga akan merasa malu hati jika tidak mampu memenuhi harapan Penyimbang dan penduduk Karangputih. Oleh sebab itu, kami laksanakan dulu apa yang telah menjadi tugas dan kewajiban kami. Jika Allah mengizinkan kami berhasil, tentunya hal itu berkat doa dan usaha kita semua." (Susilowati, 2017:13)

Kutipan di atas memperlihatkan bagaimana keyakinan yang kuat akan pertolongan dari Tuhan, dan keyakinan tentang semua yang terjadi atas manusia adalah atas seizin Tuhan, jika Tuhan berkehendak maka terjadilah, dan jika Tuhan tidak berkenendak, maka semuanya tidak mungkin terjadi. Selain itu, pada kutipan di atas juga memperlihatkan jika usaha yang maksimal dan ditambah dengan doa yang tulus, Tuhan pasti memberikan hasil yang terbaik menurut-Nya.

Selain meyakini bahwa Tuhanlah penolong sebaik-baiknya, hubungan manusia dengan Tuhan lainnya adalah berserah diri kepada Tuhan. Hal ini terlihat dalam kutipan berikut ini.

"Saya belum dapat memastikan kekuatan mereka. Saya juga tidak dapat memastikan apakah saya sanggup menghadapi mereka. Namun, mohon doa dari Penyimbang dan seluruh penduduk Karangputih. Mudah-mudahan Allah meridai doa dan usaha kita untuk menghancurkan kekuatan jahat itu." (Susilowati, 2017:18)

Manusia sebagai makhluk sempurna ciptaan Tuhan, sudah seharusnya jika selalu berdoa hanya kepada Tuhan dengan cara berserah diri. Meminta pertolongan hanya kepada Tuhan semata. Nilai budaya yang terdapat dalam kutipan di atas ialah hendaknya manusia selalu berdoa dan meminta pertolongan hanya kepada Tuhan Yang Maha Esal, dalam segala urusannya dan percaya bahwa Tuhan akan memberikan pertolongan kepada manusia.

"Datuk Tuan Budian bertahan dari semua gangguan dan keadaan itu. Dia terus memusatkan pikiran hanya kepada Allah. Dia memohon perlindungan dan kekuatan dari-Nya." (Susilowati, 2017:19)

Salah satu keyakinan manusia terhadap Tuhan adalah hanya meminta perlindungan dan kekuatan hanya kepada Tuhan. Hal ini tergambar dalam kutipan 
di atas bahwa saat mendapat gangguaan dari musuh, walaupun Datuk Tuan Budian Sakti, beliau tetap meminta pertolongan kepada Tuhan. Meminta pertolongan kepada Tuhan berhubungan dengan sikap manusia yang mempercayai bahwa Tuhan Maha Pemberi Pertolongan. Meminta perlindungan hanya kepada Tuhan yang memberikan keselamatan kepada manusia. Nilai budaya meminta perlindungan dan pertolongan kepada Tuhan berfungsi mengarahkan dan menjaga manusia untuk meminta pertolongan hanya kepada Tuhan pemilik semesta.

Pada cerita rakyat Sultan Domas Pemimpin yang Sakti dan Baik Hati nilai budaya hubungan manusia dengan Tuhan antara lain rajin berdoa, bersyukur kepada Tuhan dan percaya akan rejeki semua berasal dari Tuhan. Data yang mewakili nilai budaya dalam hubungan manusia dengan Tuhan yang terdapat dalam cerita rakyat "Sultan Domas Pemimpin yang Sakti dan Baik Hati" adalah sebagai berikut.

"Domas tidak perlu khawatir soal rejeki. Selalu saja ada orang yang membutuhkan bantuannya. Hari ini Domas diminta merapihkan pagar rumah atau mengerjakan pekerjaan lain. Domas percaya ia akan selalu mendapatkan rejeki apabila ia rajin bekerja dan selalu berdoa." (SD, 2017:5)

Kutipan di atas menggambarkan bagaimana keyakinan Domas akan rejeki yang diperolehnya. Rejeki akan datang dengan sendirinya ketika manusia mau berusaha dan berdoa kepada Tuhan. Semua rejeki yang diterima manusia tidak lain adalah pemberian dari Tuhan. Nilai Budaya yang terkandung dalam kutipan diatas adalah nilai budaya mempercayai semua rejeki sudah diatur dan ditetapkan oleh Tuhan, tinggal manusia yang harus berusaha dan berkerja untuk mendapatkan rejeki itu.

"Tak terasa waktu berlalu dengan cepat. Beberapa tahun kemudian, Domas sudah tumbuh menjadi laki-laki dewasa dan bijaksana. Ia membangun hidupnya dengan bekerja keras. Selain itu, Domas selalu rajin berdoa dan beribadah."(Nugrahani, 2017:25)

Kutipan di atas menggambarkan bagaimana Domas selain rajin berkerja, dia juga tidak pernah meninggalkan ibadahnya. Ibadah adalah cara manusia berinterksi dengan Tuhan. Menjalankan Ibadah wajib bagi manusia agar selalu mendapat rahmat dari Tuhan. Nilai budaya yang tercermin dalam kutipan di atas ialah bahwa manusia jika ingin mendapatkan rahmat dari Tuhan, janganlah meninggalkan ibadah kepada Tuhan.

"Dua benda itu dijunjungnya. Ia bersujud dan bersyukur atas berkah yang dilimpahkan kepadanya. Ia berharap anugerah itu tidak hanya berguna bagi dirinya, tetapi juga bagi seluruh penduduk Waykampung yang memperlukan pertolongan."(Nugrahani, 2017: 26)

Pada kutipan data di atas memperlihatkan bahwa Domas selalu bersyukur atas apa yang diperolehnya dan atas apa yang didapatnya, Domas tidak mau memiliki sendiri, Domas selalu berbagi kepada penduduk Waykampung. Dengan selalu bersyukur atas apa yang telah diterima dan selalu berbagi dengan orang lain merupakan suatu hal yang terpuji. Nilai budaya yang didapat dalam kutipan 
Tuah Talino

Tahun XIII Volume 13 Nomor 2 Edisi 6 Desember 2019

ISSN 0216-079X E-ISSN 2685-3043

Balai Bahasa Kalimantan Barat

tersebut adalah bahwa jika selalu bersyukur atas nikmat yang diberikan Tuhan. Banyak cara untuk mensyukuri nikmat Tuhan, salah satunya dengan berbagi kepada sesama.

\section{Nilai Budaya dalam Hubungan Manusia dengan Orang Lain}

Nilai budaya dalam hubungan manusia dengan orang lain menunjukkan bahwa manusia sebagai makhluk sosial, memerlukan orang lain orang lain dalam kehidupannya. Manusia sebagai makhluk sosial, sudah tentu tidak bisa hidup sendiri, manusia sebagai makhluk sosial memerlukan orang lain agar dapat memenuhi kebutuhan hidupnya. Komunikasi yang dilakukan antara manusia dengan manusia yang lain, merupakan salah satu wujud interaksi sosial dalam masyarakat.

Nilai-nilai budaya hubungan manusia dengan masyarakat pada cerita rakyat lampung Hikayat Datuk Tuan Budian antara lain, sifat bergotong-royong, hormat menghormati, bertanggung jawab, dan sifat mementingkan kepentingan umum. Di bawah ini akan mendeskripsikan data yang berkaitan dengan nilai budaya dalam hubungan manusia dengan masyarakat.

"Penduduk Negeri karangputih hidup rukun dan suka bergotong royong. Jika ada salah satu anggota masyarakat yang kesusahaan, ia akan membantu bersama-sama. Sebaliknya, jika ada yang mendapat kebahagiaan, yang lain juga turut merasakan kebahagiaan itu." (Susilowati, 2017: 3)

Manusia sebagai makhluk sosial, pasti membutuhkan bantuan orang lain dalam kehidupannya. Gotong royong dan saling membantu adalah salah satu nilai budaya yang dimiliki masyarakat. Jika hidup bergotong royong dan saling membantu, pekerjaan yang sulit pun, akan terasa mudah karena dikerjakan dengaan bersama-sama. Nilai Budaya yang terdapat dalam kutipan di atas adalah nilai budaya saling tolong menolong sesama manusia.

"Datuk Tuan Budian memantapkan tekad walaupun masih menyimpan kekhawatiran dan keraguan dalam hati. Namun, panggilan nuraninya untuk menolong penduduk Karangputih menghapus segala kekhawatiran dan keraguan itu. Dia bertekad, lebih baik mati karena berjuang daripada menjadi pengecut yang lari dari bahaya." (Susilowati, 2017:10)

Selain bergotong royong, nilai budaya hubungan manusia dengan orang lain adalah nilai kasih sayang. Nilai kasih sayang pada kutipan ini diperlihatkan oleh Datuk Tuan Budian yang rela berkorban jiwa dan raga, untuk dapat menolong penduduk karangputih, agar terbebas dari ancaman musuh.

"Datuk Tuan Budian adalah seorang pemimpin yang sangat dihormati. Dia sangat sakti, tetapi pendiam dan banyak akal. Dia juga sangat bertanggung jawab kepada rombonganya." (Susilowati, 2017: 7)

Kutipan di atas menjelaskan bagaimana seorang pemimpin yang bertanggung jawab kepada anggotanya (rombongannya). Seorang pemimpin yang baik, bertanggung jawab, dan peduli terhadap anggotanya adalah salah satu nilai budaya hubungan manusia dengan masyarakatnya. Jika pemimpin baik dan 
Tuah Talino

Tahun XIII Volume 13 Nomor 2 Edisi 6 Desember 2019

ISSN 0216-079X E-ISSN 2685-3043

Balai Bahasa Kalimantan Barat

bertanggung jawab, dia pasti akan dihormati dan disegani oleh anggotanya. Selain bertanggung jawab, nilai budaya yang berhubungan antara manusia dengan masyarakat adalah mempunyai simpati kepada masyarakat lainnya. pada kutipan di bawah ini menjelaskan walaupun Datuk Tuan Budian sudah menjadi pemimpin, beliau masih tetap memperhatikan keperluan, kebutuhan hidup rombongan atau masyarakatnya.

"Sosok Datuk Tuan Budian sederhana tetapi penuh wibawa. Selain bijaksana, dia juga penuh perhatian kepada rombongannya. Hal itu menjadi ciri kepemimpinan yang melekat pada dirinya. Meskipun ia tidak banyak bicara, apa yang diucapkan selalu penuh makna." (Susilowati, 2017:12)

Pada cerita rakyat Sultan Domas Pemimpin yang Sakti dan Baik Hati, Nilai budaya hubungan manusia dengan masyarakat antara lain, saling membantu terhadap sesama, hidup rukun, dan keteladanan. Data tentang nilai budaya hubungan manusia dengan masyarakat, akan dideskripsikan di bawah ini.

"Penduduk kampung menyayangi Domas karena ia adalah anak yang baik. Ia selalu siap memberikan tenaganya untuk membantu orang. Ia sangat rajin bekerja dan selalu bersikap sopan.” (Nugrahani, 2017: 3)

Kutipan data di atas menggambarkan bagaimana jiwa menolong Domas yang tinggi. Domas selalu memberikan bantuan kepada penduduk kampung yang membutuhkannya. Karena mempunyai jiwa penolong dan mau membantu, Domas disukai oleh penduduk kampung. Nilai budaya hubungan manusia dengan masyarakat pada kutipan di atas adalah sifat saling membantu dan penolong.

"Domas selalu hidup rukun dengan para tetangga. Hampir semua orang dikampungnya mengasihi anak yatim piatu yang hidup sebatang kara itu. Mereka tidak segan membantu Domas karena anak itu juga tidak pernah segan membantu orang-orang kampung." (Nugrahani, 2017:7)

Kutipan di atas menceritakan bahwa penduduk kampung, selalu hidup rukun dan saling membantu jika salah satu dari mereka mengalami kesusahan. Nilai budaya hubungan manusia dengan masyarakat pada kutipan di atas adalah saling tolong menolong.

"Sejak peristiwa ular dan buaya, Domas makin dihormati oleh penduduk Waysekampung. Kesaktian kedua benda pusaka milim Domas tidak hanya terlihat dalam peristiwa ular dan buaya. Domas membantu setiap orang yang membutuhkan dengan kedua benda itu. Kebaikan, keramahan, kejujuran, dan keserhanaan Domas menjadi teladan bagi siapa saja. Hal itu tentu membuat Domas mendapatkan perhatian dan kasih sayang dari semua orang." (Nugrahani,2017:29)

Kutipan di bawah ini menjelaskan bagaimana Sultan Domas menjadi panutan warga Waysekampung. Segala sifat baik yang dimiliki oleh Domas menjadi dasar para penduduk kampung mengangkat Domas menjadi pemimpin mereka, dan semua penduduk kampung mengikuti dan mengamalkan sifat-sifat 
baik Sultan Domas. Nilai budaya hubungan manusia dengan masyarakat pada kutipan di bawah adalah keteladanan karena sifat baiknya.

"Orang-orang semakin segan pada Sultan Domas. Kampung tempat tinggalnya pun semakin mamkur. Penduduknya hidup rukun dan sejahtera. Mereka mengamalkan semua pelajaran yang diberikan oleh Sultan Domas. Saat Sultan Domas meninggal, semua penduduk Waysekampung merasa kehilangan. Sultan Domas dimakamkan di pinggir Waysekampung." (Nugrahani, 2017:41)

"Penduduk Negeri karangputih hidup rukun dan suka bergotong royong. Jika ada salah satu anggota masyarakat yang kesusahan, ia akan membantu bersama-sama. Sebaliknya, jika ada yang mendapat kebahagiaan, yang lain juga turut merasakan kebahagiaan itu." (Susilowati, 2017: 3)

Pada cerita rakyat Sultan Domas Pemimpin yang Sakti dan Baik Hati, nilai budaya hubungan manusia dengan orang lain adalah berjiwa penolong, dermawan, dan cinta damai. Di bawah ini akan adalah data tentang nilai budaya hubungan manusia dengan orang lain, antara lain adalah

"keesokan harinya, Domas menepati janji membantu tetangganya itu. Pagipagi sekali, ia sudah mengasah parang. Sebelum berangkat, ia sarapan dengan segelas air putih hangat dan sepotong singkong rebus. Ia datang ke rumah tetangganya itu setelah membereskan rumah dan memberi makan ayam-ayam dan kambing peliharaannya."(Nugrahani, 2017:5)

Kutipan di atas menggambarkan bagaimana sifat Domas yang sering membantu orang lain. Apapun pekerjaan yang halal akan dilakukan oleh Domas dengan senang hati, hal ini yang membuat penduduk kampung senang terhadapnya dan juga tidak segan-segan mereka membantu jika Domas membutuhkan bantuan. Nilai budaya, hubungan manusia dengan orang lain adalah berjiwa penolong. Selain berjiwa penolong, nilai budaya lainnya adalah berjiwa dermawan dan saling berbagi. Hal tersebut terdapat pada kutipan di bawah ini

"Jika mendapat ikan banyak, ia akan menawarkan ikan-ikan itu kepada orang kampung untuk ditukar dengan beras, sayuran, atau barang keperluan lain. Bahkan, apabila ada orang meminta ikan hasil tangkapannya tanpa ditukar, Domas memberikannya dengan iklas.” (Nugrahani, 2017:7)

Kutipan di atas mengisahkan bagaimana Domas mempunyai sifat dermawan. Jika Domas sedang mendapatkan rejeki yang banyak, Domas tidak segan-segan berbagi kepada penduduk kampung.

"Suatu hari, Domas dicegat oleh sekawanan perampok. Para perampok itu meminta Domas menyerahkan hartanya. Domas menjelaskan siapa dirinya dan apa saja yang dibawanya. Sedapat mungkin, ia menghindari menyelesaian dengan kekerasan. Kata-kata halus dan bersahabat seringkali 
Tuah Talino

Tahun XIII Volume 13 Nomor 2 Edisi 6 Desember 2019

ISSN 0216-079X E-ISSN 2685-3043

Balai Bahasa Kalimantan Barat

menjadi senjata yang ampuh baginya untuk mengatasi ancaman-ancaman dari orang-orang jahat."'(Nugrahani, 2017:21)

"Domas menasihati orang-orang itu. Kesaktian dan kepopuleran bukanlah hal terpenting dalam hidup, apalagi jika diraih dengan cara yang salah. Kelima orang terdiam mendengarkan nasihat Domas. Mereka takjub atas ketinggian budi serta keredahan hati pemuda itu."(Nugrahani, 2017:37)

Selain sifat dermawan, Domas juga mempunyai sifat cinta damai, hal tersebut digambarkan pada kutipan di atas. Walaupun ada yang berbuat jahat kepada Domas, sedapat mungkin, Domas tidak memakai cara kekerasan untuk menyelesaikan masalahnya.

\section{Nilai Budaya dalam Hubungan Manusia dengan Dirinya Sendiri}

Sebagai makhluk individu, manusia juga berhak atas dirinya sendiri. Manusia dalam prosesnya harus menjadi lebih baik dari sebelumnya. Manusia dalam beberapa momentum harus mengandalkan dirinya sendiri, tanpa ada campur tangan manusia lainnya. Nilai budaya hubungan manusia dengan dirinya sendiri pada cerita rakyat Hikayat Datuk Tuan Budian antara lain keberanian, kewaspadaan, dan menyakini ajaran agama. Data tentang nilai budaya hubungan manusia dengan dirinya sendiri terdapat pada kutipan di bawah ini.

“ 'Bersabarlah menunggu saya kembali! Namun, jika sudah tiga bulan tidak ada kabar, periksalah daerah tersebut! Siapa tahu saya sudah meninggal. Jika hal itu terjadi, kuburkanlah saya di daerah itu! Uruslah jasadku seperti penyimbang mengurus saudara sendiri!' Datuk Tuan Budian berpesan seolah-olah ia tidak akan kembali lagi." (Susilowati, 2017:18)

Kutipan di atas memperlihatkan nilai keberanian yang dimiliki oleh Datuk Tuan Budian. Memiliki ilmu yang sakti dan bermaksud ingin menolong warga Karangputih, Datuk Tuan Budian memutuskan untuk melawan siluman, sendirian. Datuk Tuan Budian memilih melakukannya sendiri agar tidak ada korban dari warga. Selain keberanian, kewaspadaan dan ketenangan juga dimiliki oleh Datuk Tuan Budian.

Kutipan data di bawah menggambarkan kewaspadaan dan ketenangan yang dimiliki oleh Datuk Tuan Budian. Ketenangan disini adalah bagaimana Datuk Tuan Budian, dapat mengatur emosinya dan tidak terpancing oleh gangguan siluman. Ketenangan disini juga menggambarkan bahwa Datuk Tuan Budian tahu kapan harus melawan para siluman tersebut.

"Datuk Tuan Budian meningkatkan kewaspadaannya, tetapi dia tetap terlihat santai seolah-olah dia tidak terganggu oleh kedatangan makhluk yang menyeramkan itu. Bahkan, saat siluman itu menghardik, Datuk Tuan Budian tetap diam dan tenang. (Susilowati, 2017:19)

Pada cerita rakyat Sultan Domas Pemimpin yang Sakti dan Baik Hati. Nilai budaya hubungan manusia dengan dirinya sendiri dalam cerita rakyat ini antara lain, sabar, syukur, mandiri, pekerja keras, keteladanan, dan bijaksana.

"Domas tidak pernah menyesali kehidupannya yang sederhana. Ia yakin, suatu saat ini. Tuhan akan memberinya kehidupan yang lebih baik. Ia hanya perlu senantiasa berdoa, berusaha, dan bersabar." (Nugrahani, 2017:8) 
Tuah Talino

Tahun XIII Volume 13 Nomor 2 Edisi 6 Desember 2019

ISSN 0216-079X E-ISSN 2685-3043

Balai Bahasa Kalimantan Barat

Kutipan di atas mengisahkan bagaimana Domas tidak menyesali kehidupannya. Domas sangat bersyukur atas apa yang telah diberikan Tuhan kepadanya, dan tidak lupa Domas selalu berdoa agar mendapatkan kehidupan yang lebih baik. Nilai budaya hubungan manusia dengan dirinya sendiri pada kutipan di atas adalah seseorang yang mempunyai sifat sabar dan bersyukur atas apa yang telah dimilikinya. Selain sifat sabar, sifat mandiri merupakan salah satu nilai budaya hubungan dengan diri sendiri dalam cerita rakyat ini. Hal ini terdapat pada kutipan data berikut ini.

"Domas belajar hidup mandiri di tengah orang-orang yang ada di sekitarnya. Ia rajin bekerja dan selalu siap membantu siapa pun yang membutuhkannya." (Nugrahani,2017:9)

Kutipan di atas menggambarkan bagaimana sifat mandiri yang dimiliki oleh Domas. Walaupun warga kampung baik dengan Domas, tetapi Domas tidak pernah sedikitpun bergantung kepada mereka. Domas lebih memilih berkerja keras daripada meminta belas kasihan orang lain, hal ini terdapat dalam kutipan di bawah ini.

"Domas tidak pernah berkecil hati atas kemiskinannya. Ia melanjutkan kehidupannya dengan bekerja lebih keras lagi. Seringkali, tanpa diminta pun, ia akan menawarkan tenaganya untuk membantu orang lain. Oleh karena itu, tubuhnya menjadi lebih kuat dan berotot dibandingkan dengan teman-teman sebayanya.”(Nugrahani, 2017:10)

Kutipan di atas menggambarkan tentang Domas yang hari-harinya diisi dengan bekerja dan membantu orang-orang disekitarnya. Tak heran jika tubuh Domas lebih besar dan berotot dibandingkan teman-temannya. Nilai budaya yang terdapat dalam dua kutipan di atas adalah nilai budaya berkerja keras. Kerja keras adalah upaya yang yang terus dilakukan tidak pernah menyerah dan bersungguh-sungguh dalam menyelesaikan pekerjaan. Jika manusia selelu berkerja keras dan sungguh-sungguh pasti akan memperoleh hasil yang maksimal dan sesuai dengan apa yang diinginkan.

"Sifat pemaaf Domas telah menjadi sumber inspirasi bagi mereka untuk membaiki kesalahan di masa lalu. Mereka ingin mencontoh sifat baik Domas. Mereka ingin hidup bermasyarakat dengan saling membantu dan saling menasihati dalam kebaikan seperti yang dilakukan oleh Domas." (Nugrahani, 2017:28)

Kutipan data di atas menggambarkan sosok Domas yang menjadi teladan bagi penduduk Waysekampung. Segala sifat baik yang dimiliki oleh Domas menjadi sumber inspirasi bagi penduduk kampung yang ingin dirinya menjadi lebih baik.

Memiliki sifat teladan bagi semua orang dikampungnya, Domas pun diangkat menjadi pemimpin kampungnya. Warga Waysekampung, bersepakat mengangkat Domas menjadi pemimpin mereka dan memberikan gelar Sultan 
Domas. Bijaksana adalah salah satu nilai budaya hubungan antara manusia dengan dirinya sendiri. Hal ini terdapat pada kutipan data di bawah ini.

"Seiring waktu, Domas juga semakin bijaksana. Ia memiliki karisma yang sangat besar. Domas telah diangkat menjadi pemimpin Waysekampung. Orang-orang Waysekampung makin hormat padanya. Domas pun mendapat panggilan baru, yakni Sultan Domas. Panggilan itu mengukuhkannya sebagai seorang pemimpin." (Nugrahani, 2017:39)

\section{Nilai Budaya dalam Hubungan Manusia Dengan Alam}

Hubungan manusia dengan alam yaitu bagaimana manusia memandang alam karena masing-masing kebudayaan mempunyai persepsi yang berbeda tentang alam (Ayuningtyas, 2015:11). Untuk dapat bertahan hidup, manusia membutuhkan alam untuk dapat memenuhi semua kebutuhan. Alam adalah sumber kehidupan, karenanya manusia sudah sepatutnya menjaga dan melestarikan alam sekitarnya. Nilai budaya hubungan manusia dengan alam, dalam cerita rakyat Hikayat Datuk Tuan Budian antara lain memanfaatkan alam dengan sebaik-baiknya. Data yang mewakili nilai budaya tersebut adalah sebagai berikut.

"Negeri Karangputih sangat subur. Tanahnya kehitam-hitaman karena banyak mengandung humus sehingga baik untuk bercocok tanam. (Susilowati, 2017:3)

Kutipan data di atas menggambarkan bagaimana alam memberikan kesuburan untuk dapat dimanfaatkan oleh manusia. Oleh karena itu, manusia harus dapat lebih bijak untuk dapat mengolah sumber alam yang ada di sekitarnya. Seperti kutipan di bawah ini, mengisahkan para penduduk yang dipimpin oleh Tuan Budian menanfaatkan kesuburan tanahnya untuk ditamani berbagai macam tanaman dan sebagian lain mengambil hasil laut seperti ikan.

"Mereka menanam kopi, lada, dan palawija. Sebagian yang lain, bekerja sebagai nelayan. Mereka turun kelaut setiap hari untuk menangkap ikan. Petani dan nelayan saling bertukar hasil pertanian dan tangkapan ikan untuk memenuhi kebutuhan sehari-hari." (Susilowati, 2017:3)

Nilai budaya yang berhubungan manusia dengan alam, pada dua kutipan di atas adalah manusia menanfaatkan hasil alam seperti berkebun dan menjadi nelayan. Salah satu sumber alam yang diberikan Tuhan adalah perikanan. Akan tetapi, jika manusia tidak pintar dalam mengelolanya, sumber daya alam itu akan habis. Seperti halnya kopi dan lada yang menjadi sumber daya alam perkebunan. Oleh karena itulah, pada cerita ini untuk menjaga keberlangsungan sumber daya alam, mereka mengambil secukupnya, dan bersama-sama saling bertukar hasil bumi, untuk memenuhi kebutuhan mereka.

Pada cerita rakyat Sultan Domas Pemimpin yang Sakti dan Baik Hati. Nilai budaya yang berhubungan manusia dengan alam adalah cinta terhadap lingkungan. Data yang mewakili nilai budaya pada cerita ini adalah sebagai berikut.

"Mereka mengikuti ajakan Domas untuk hidup saling menghargai. Mereka mengambil keperluan hidup dari alam secukupnya tanpa merusak lingkungan. Jika ada kerusakan, mereka akan segera memperbaiki secara bersama-sama."(Nugrahani, 2017:23) 
“ 'Jangan membuang sampah ke sungai, ya Nak! Sungai adalah sumber kehidupan bagi semua makhluk yang ada di sini. Kalau kita membuang sampaah di sungai, airnya jadi tidak layak lagi digunakan untuk minum, mandi, dan keperluan lain. Bagaimana mungkin kita dapat hidup sehat tanpa air bersih? Jagalah kebersihan sungai kita, ya Nak!' Domas menasehati anak itu."(Nugrahani, 2017:23)

Kutipan di atas menggambarkan bagaimana Domas cinta terhadap lingkungan sekitarnya. Domas mengajak para penduduk kampung untuk menjaga lingkungan agar bersih, hal ini dikarenakan bahwa, alam adalah sumber penghidupan bagi mereka. Menjaga alam dan tidak merusaknya merupakan salah satu manusia menghargai alam, yang telah memberikan manusia sumber kehidupan.

\section{PENUTUP}

Berdasarkan hasil kajian yang dilakukan dapat disimpulkan bahwa nilainilai budaya yang terdapat dalam cerita rakyat Lampung yang berjudul Hikayat Datuk Tuan Budian dan Sultan Domas Pemimpin yang Sakti dan Baik Hati memiliki nilai-nilai budaya di dalamnya, yang dapat dicontoh atau diteladani oleh para pembaca. Nilai budaya yang terdapat pada cerita rakyat Hikayat Datuk Tuan Budian antar lain, nilai budaya manusia yang berhubungan dengan Tuhan adalah, keyakinan, berdoa kepada Tuhan. Nilai budaya manusia yang berhubungan dengan masyarakat adalah sifat bergotong-royong, hormat menghormati, bertanggung jawab, dan sifat mementingkan kepentingan umum. Nilai budaya manusia yang berhubungan dengan orang lain adalah berjiwa penolong dan kasih sayang. Nilai budaya manusia yang berhubungan dengan diri sendiri adalah keberanian, kewaspadaan, dan menyakini ajaran agama, dan Nilai budaya manusia yang berhubungan dengan alam adalah memanfaatkan alam dengan sebaik-baiknya.

Selanjutnya, nilai budaya yang terdapat dalam cerita rakyat Sultan Domas Pemimpin yang Sakti dan Baik Hati adalah nilai budaya yang bergubungan manusia dengan Tuhan antara lain, rajin berdoa, bersyukur kepada Tuhan dan percaya akan rejeki semua berasal dari Tuhan. Nilai budaya hubungan manusia dengan masyarakat antara lain saling membantu terhadap sesama, hidup rukun, dan keteladanan. Nilai budaya hubungan masyarakat dengan orang lain antara lain berjiwa penolong, dermawan, dan cinta damai. Nilai budaya hubungan manusia dengan dirinya sendiri antara lain sabar, syukur, mandiri, pekerja keras, keteladanan, dan bijaksana, dan nilai budaya hubungan manusia dengan alam antara lain cinta terhadap lingkungan.

\section{DAFTAR PUSTAKA}

Ayuningtyas, Dian. (2015). Nilai Budaya Pada Novel Gugur Bunga Kedaton Karya Wahyu H.R: Kajian Antropologi Sastra dan Implementasinya Dalam Pembelajaran Sastra Di Sma. Naskah Publikasi. Universitas Muhammadiyah Surakarta. 
Tahun XIII Volume 13 Nomor 2 Edisi 6 Desember 2019

ISSN 0216-079X E-ISSN 2685-3043

Balai Bahasa Kalimantan Barat

Danandjaja, James. (1997). Folklor Indonesia: Ilmu Gosip, Dongeng, dan Lainlain. Jakarta: Pustaka Utama Grafiti.

Djamaris, Edward. (1993). Menggali Khazanah Sastra Melayu Klasik. Jakarta: Balai Pustaka.

Endraswara, Suwardi. (2013). Folklor Nusantara: Hakikat, Bentuk, dan Fungsi. Yogyakarta. Penerbit Ombak Dua.

Hafidhah, Nurul,dkk. (2017). Analisis Nilai Budaya Dalam Novel Lampuki Karya Arafat Nur. Jurnal Ilmiah Mahasiswa Jurusan PBSI Vol. 2 No. 4, Oktober 2017:393-399. Universitas Syah Kuala.

Koentjaraningrat. (1987). Manusia dan Kebudayaan di Indonesia. Yogyakarta: Djambatan.

Luxemburg, Jan Van.et al. (1989). Pengantar Ilmu Sastra. Terjemahan Dick Hartoko. Jakarta: Gramedia Pustaka Utama.

Moleong, Lexy J. (2007). Metodologi Penelitian Kualitatif. Bandung: PT. Remaja Rosdakarya.

Nugrahani, Yuli. (2017). Sultan Domas Pemimpin yang Sakti dan Baik Hati. Lampung: Kantor Bahasa Provinsi Lampung.

Susilowati. (2017). Hikayat Datuk Tuan Budian. Lampung: Kantor Bahasa Provinsi Lampung. 